\title{
The Effect of Perceived Organizational Support and Transformational Leadership on Affective Commitment and Employee Performance
}

\author{
Isthofaina ASTUTY ${ }^{1}$, Udin UDIN ${ }^{2}$
}

Received: July 18, 2020 Revised: August 23, 2020 Accepted: September 03, 2020

\begin{abstract}
Recognizing the vital role of employees in achieving optimal performance and sustainable competitive advantage as expected, organizations need to facilitate high support for employees, implement appropriate leadership styles, and increase affective commitment within the organization. Therefore, the objective of this study is to analyze and explore: (1) the effect of perceived organizational support (POS) on employee performance and affective commitment; (2) the effect of transformational leadership on employee performance and affective commitment; and (3) the effect of affective commitment on employee performance. The covered population in this study were all employees (including managers, supervisors, and functional staff) who worked in the stone milling companies in Central Java, Indonesia. Data obtained in this study were processed statistically employing structural equation modeling (SEM) with the SmartPLS 3 software package. Based on the data analysis results on 103 respondents, this study concluded that POS had a significant effect on affective commitment and employee performance as well as transformational leadership on affective commitment and employee performance. Furthermore, affective commitment also had a significant effect on employee performance. Thus, the results of this study, theoretically and practically, can be used by all parties concerned to improve employee performance and maintain a sustainable competitive advantage.
\end{abstract}

Keywords: Perceived Organizational Support, Transformational Leadership, Affective Commitment, Employee Performance

JEL Classification Code: D22, L20, L25

\section{Introduction}

To promote innovative performance, perceived organizational support and transformational leadership are essential factors. Previous studies of proactive employees have focused on their tendency to innovate services in creating an impression on customers with personalized, different, exclusive, unique, and memorable experiences (Chen \& Kao, 2014; Li \& Yuan, 2017).

Employee performance is considered very important to encourage organizational growth. More clearly and specifically, for organizations engaged in the service sector, employee performance is a determining and driving factor for higher

${ }^{1}$ First Author. Business and Economics Faculty, Universitas Muhammadiyah Yogyakarta, Yogyakarta, Indonesia

${ }^{2}$ Corresponding Author. Business and Economics Faculty, Universitas Muhammadiyah Yogyakarta, Indonesia [Postal Address: Jl. Brawijaya, Tamantirto, Kec. Kasihan, Yogyakarta, 55183, Indonesia] Email: udin_labuan@yahoo.com

(c) Copyright: The Author(s)

This is an Open Access article distributed under the terms of the Creative Commons Attribution Non-Commercial License (https://creativecommons.org/licenses/by-nc/4.0/) which permits unrestricted non-commercial use, distribution, and reproduction in any medium, provided the unrestricted non-commercial
original work is properly cited. growth (Fong \& Snape, 2015). The performance of employees who are focused on service is crucial to achieving business goals and maintaining a competitive advantage (Chiang \& Hsieh, 2012; Karatepe \& Sokmen, 2006). Therefore, the management of the organization must encourage and continue to train employees to improve their performance.

In a fast-paced world, organizations must innovate to stay competitive. Employee behavior that adds and contributes to the formation and application of desired new ideas will lead to organizational-level innovation, which is indispensable for achieving organizational effectiveness, competitive advantage, and the organization's long-term survival (Shanker et al., 2017). Therefore, it is essential to identify, investigate and explore the factors that encourage, influence, and improve employee performance.

In the comprehensive literature review related to the relationship of perceived organizational support (POS) and performance of employee, there is still a long debate. The results of Chen et al. (2020) found that POS had a significant effect on employee performance. It is also consistent with the findings of Abou-Moghli (2015), Cullen et al. (2014), Guan et al. (2014), Sears et al. (2016), Shaheen and Krishnankutty (2018), and Xiong and King (2018) that POS had a significant positive effect on performance of employee in organization. 
However, some findings above are very contradictory to the results of Chiang and Hsieh (2012), Wann-Yih and Htaik (2011), who found that POS had a significant negative effect employee performance. Whereas Alpkan et al. (2010), Yavas et al. (2010) found that POS had a partial effect on employees' innovative performance.

The findings of Buil et al. (2019), Kammerhoff et al. (2019), Luo et al. (2019) related to the linkage of transformational leadership and performance of employee showed that transformational influenced significantly on employee performance. However, Eliyana et al. (2019), Jaiswal and Dhar (2015) showed contradictory results that transformational leadership did not significantly influence employee performance.

Based on the gaps in the study results, the authors are motivated to conduct further research with the aim of confirming the results of previous research, namely by adding affective commitment as a mediating variable linking POS and transformational leadership to employee performance. The novelty in this study is not only located in the mediating variables that connect POS and transformational leadership to employee performance, but also on the dimensions and measurement indicators used in research.

Theoretically, this research can enrich the literature on the relationship between POS and transformational leadership on employee performance mediated by affective commitment. Practically, this research can be used by all parties concerned to improve employee performance and maintain a sustainable competitive advantage.

\section{Literature Review}

\subsection{Social Exchange Theory}

In this study, the social exchange theory (SET) was used as a theoretical foundation for three purposes. First, as stated by the social exchange theory, trust and commitment are the basis of exchange behavior between individuals. Second, social exchange theory can be used to explain the subjective benefit and cost analysis (Kankanhalli et al. 2005), where individuals are involved in a relationship when they assume that the perceived benefits of social action are higher than the potential costs incurred. Third, social exchange theory views exchange as a social behavior that can produce tangible outcomes (for example, innovative products) and intangible outcomes (for example, self-belongings).

According to SET, when organizational leaders provide autonomy and support to employees, employees tend to reciprocate behaviors to leaders with positive attitudes and behaviors. Employees that have formed high-quality links with their leaders continue to produce higher rates of social care, benefits and high performance (Cheong et al., 2016; Eisenberger et al., 2014).

\subsection{Perceived Organizational Support}

According to the theory of perceived organizational support (POS), employees attribute personality, prioritizing contributions to the organization to achieve a high level of welfare. Employees want to keep and take care of the benefits and financial relationships they feel in a reciprocal relationship (Park, Newman et al., 2016). In POS theory, when employees feel that they are supported by the organization, their sense of responsibility for the organization's welfare and goals increases (Park et al., 2016).

Rhoades and Eisenberger (2002) reported that when employees get support from the organization's peers, they feel more liable for their work. Employees with high organizational support perform greater and superior creativity (Shantz et al., 2016), higher commitment (Gupta et al., 2016), and optimal performance (Vatankhah et al., 2017).

\subsection{Transformational Leadership}

Leadership is an essential component that influences the work environment, and the way employees view their work (Pancasila et al., 2020). Transformational leadership has been conceptualized as a concept of multi-dimensional leadership. The concept of transformational leadership originated from Burns (1978) in his seminal work and subsequently developed by Bass (1985), resulting in changes in followers, encouraging them to go beyond personal interests by considering organizational goals and making them think from different points of view.

In the study by Avolio et al. (1999), the concept of transformational leadership unites idealized influence, individualized consideration, and intellectual stimulation to inspire employees. By using idealized influence, transformational leaders inspire the followers' thoughts by acting as role models to gain admiration, respect, honesty, trustworthiness, and loyalty, which results in the sense of collectivity among followers. Jung et al. (2003) believe that transformational leaders tend to build a work climate that allows and empowers their followers and provides sufficient support to carry out work innovations.

\subsection{Affective Commitment}

Commitment is a strong belief in a highly valued relationship that encourages 'maximum effort' to maintain it (Palmatier et al., 2007). Commitment is considered as the 'highest stage in a relational bond' (Martono et al., 2020).

In the insight of Meyer and Allen (1991), commitment to an organization can be decoded into three types, namely affective commitment (employee's emotional connection to the organization), normative commitment (moral duty 
to stay in the organization), and continuous commitment (perceived cost related to exit from the organization). Through continuous commitment, employee commitment to the organization is rooted in assessing the benefits and costs of continuing relationships. Whereas, employees' emotional attachment to the organization refers to affective commitment, which is marked by the identification of employees with high loyalty to the organization (Ganesan et al., 2010).

Affective commitment functions as a driver, which increases various competencies that benefit employees, and, in turn, promotes employee performance (Bloemer et al., 2013). Affective commitment is also essential in building long-term orientation and cooperative behavior in organizations.

\section{Hypothesis Development}

\subsection{POS, Affective Commitment, and Employee Performance}

The results of Tsai et al. (2015) found that POS had a significant effect on employee work creativity, mediated by knowledge sharing. Likewise, Guan et al. (2014) found that affective commitment and job satisfaction mediated the relationship between POS and employee performance. Employees who felt greater organizational support in their work tended to show affective commitment to the organization, which in turn, their affective commitment would lead to better and greater performance (Xiu et al., 2019).

In organizational support theory, when organizations develop employee skills and knowledge through various resources and mechanisms, employees assume that their contributions are valued by the organization and that the organization cares about their well-being. Based on the norms of reciprocity, it is to produce obligations that are felt on the part of employees to care for the organization and help the organization achieve its goals by displaying the best performance (Rhoades \& Eisenberger, 2002). Employees with high organizational support show greater creativity (Shantz et al., 2016), higher commitment (Gupta et al., 2016), optimal performance (Vatankhah et al., 2017). Thus,

H1: POS has a significant effect on employee performance.

H2: POS has a significant effect on affective commitment.

\subsection{Transformational Leadership, Affective Commitment, and Employee Performance}

A meta-analysis study by Judge and Piccolo (2004) reported that transformational leadership was positively correlated with the group and organizational performance. Likewise, Buil et al. (2019), Piccolo and Colquitt (2006) concluded that transformational leadership improved employee performance. Furthermore, the results of the study have also shown that transformational leadership was positively related to affective commitment in the organization in various samples (Bono \& Judge, 2003; Dumdum et al., 2002; Gyensare et al., 2016; MañasRodríguez et al., 2020; Stinglhamber et al., 2015). Hence,

H3: Transformational leadership has a significant effect on employee performance.

H4: Transformational leadership has a significant effect on affective commitment.

\subsection{Affective Commitment and Employee Performance}

Hakimian et al. (2016) stated that affective commitment had a significant effect on innovative work behavior of employees. Employees who had affective commitments tended to share knowledge and display more innovative in organizations. Employees with affective commitment are very involved in the organization, generating new ideas and innovative suggestions, and always improving performance (Colla et al., 2019; Jatmiko et al., 2020; Jauhari et al., 2017; Vuong et al., 2020). Thus,

H5: Affective commitment has a significant effect on employee performance.

\section{Research Methods}

This research used a quantitative design. In this regard, the type of research used was explanatory, meaning that this research emphasizes the relationship between variables by testing hypotheses (Kumar, 2005).

\subsection{Data Collection Method}

In this study, the data collection methods used were:

1. Primary data collection was done by distributing questionnaires to respondents. Questionnaires were distributed using a Likert scale with a score of 1 to 5 , which would then be filled in by respondents as research samples that showed their agreement to specific questions with answer choices ranging from strongly disagree to the strongly agree.

2. Secondary data collection was carried out by a literature study, which included data on the number of organizational employees, organizational policies, and others. 


\subsection{Population and Sample}

The population in this study were all employees (including managers, supervisors, and functional staff) who worked in stone milling companies in Central Java, Indonesia, in the districts of Batang, Demak, and Pati. Hair et al. (2010) stated that there are no general rules or formulas that can provide the right solution to determine the number of observations needed in Structural Equation Modeling (SEM) so that researchers are free to determine the sample size needed to obtain results, which can be trusted. However, in general, the researchers determined the study sample based on the number of indicators multiplied by 5 to 10 (Nicolaou \& Masoner, 2013). Therefore, the sampling technique in this study employed purposive sampling with the following criteria: (a) having a minimum of three years of work experience; (b) actively involved in the organization.

\subsection{Measurements}

The measurements of each variable are described in Table 1 .

\subsection{Data Analysis Technique}

The data to be obtained in this study were processed statistically applying Structural Equation Modeling (SEM) with the SmartPLS 3 software package. The SEM-based analysis technique is very convenient in developing, expanding and advancing theories, especially when second order and even third-order factors contribute a better understanding of the relationship that might not be apparent at first (Astrachan et al., 2014).

\section{Results and Discussion}

The questionnaire in this study was distributed to 200 employees (including managers, supervisors, and functional staff) who worked in stone milling companies in Central Java, Indonesia. There were 121 questionnaires that were returned, but those that were valid for processing and analysis were 103 questionnaires. Table 2 below describes in detail the characteristics of the respondents involved in this study.

Table 2 shows that the respondents covered and involved in this study were dominated by men $(91.26 \%)$, with women $(8.74 \%)$. In terms of age, $37.86 \%$ were between 31 and 40,34.95\% between 41 and 50, 22.34\% over 51 , and the rest $(4.85 \%)$ were under 30 years. In terms of education, the majority of respondents was dominated by high school graduates $(51.46 \%)$, then S1 (bachelor degree) (27.18\%), D3 (diploma) (14.56\%), and SMP (junior high school) $(6.8 \%)$. In terms of tenure, $40.78 \%$ of respondents have worked for 9-11 years, and only $16.5 \%$ have worked for over 12 years.

Table 1: Measurements

\begin{tabular}{|c|c|c|c|}
\hline No. & Variables & Indicators & Source \\
\hline 1 & $\begin{array}{l}\text { Perceived } \\
\text { Organizational } \\
\text { Support }\end{array}$ & $\begin{array}{l}\text { - The organization values employee contributions (POS1) } \\
\text { - The organization pays attention to employee welfare (POS2) } \\
\text { - The organization cares about employees (POS3) } \\
\text { - The organization pays great attention to employees (POS4) } \\
\text { - The organization is proud of the work success of its employees (POS5) }\end{array}$ & $\begin{array}{l}\text { Rhoades and } \\
\text { Eisenberger (2002) }\end{array}$ \\
\hline 2 & $\begin{array}{l}\text { Transformational } \\
\text { Leadership }\end{array}$ & $\begin{array}{l}\text { - Describe the organization's vision clearly (TL1) } \\
\text { - Eemonstrate the right role model (TL2) } \\
\text { - Encourage the achievement of shared goals (TL3) } \\
\text { - Encourage followers to show their best performance (TL4) } \\
\text { - } \text { Pay attention to the welfare of followers (TL6) } \\
\text { - Consider follower suggestions before acting (TL7) }\end{array}$ & $\begin{array}{l}\text { Kirkman, Chen, Farh, } \\
\text { Chen, and Lowe } \\
\text { (2009); MacKenzie, } \\
\text { Podsakoff, and Rich } \\
(2001)\end{array}$ \\
\hline 3 & $\begin{array}{l}\text { Affective } \\
\text { Commitment }\end{array}$ & $\begin{array}{l}\text { - } \text { Like the organization (AC1) } \\
\text { - Integrate with the organization (AC2) } \\
\text { - } \text { Proud to be part of the organization (AC3) }\end{array}$ & $\begin{array}{l}\text { Vandenberghe, } \\
\text { Bentein, and } \\
\text { Stinglhamber (2004) }\end{array}$ \\
\hline 4 & $\begin{array}{l}\text { Employee } \\
\text { Performance }\end{array}$ & $\begin{array}{ll}\text { - } & \text { Work quality (EP1) } \\
\text { - } & \text { Work quantity (EP2) } \\
\text { - } & \text { Punctuality (EP3) } \\
\text { - } & \text { Cooperation ability (EP4) } \\
\text { - } & \text { Ability to carry out work (EP5) }\end{array}$ & $\begin{array}{l}\text { Bratton and Gold } \\
(2017)\end{array}$ \\
\hline
\end{tabular}


Table 2: Respondents Characteristics

\begin{tabular}{|c|c|c|c|}
\hline No. & Respondents Profile & Total & Percentage \\
\hline \multirow[t]{4}{*}{1.} & \multicolumn{3}{|l|}{ Gender } \\
\hline & Male & 94 & 91.26 \\
\hline & Female & 9 & 8.74 \\
\hline & Total & 103 & 100 \\
\hline \multirow[t]{6}{*}{2.} & \multicolumn{3}{|l|}{ Age } \\
\hline & $\leq 30$ year & 5 & 4.85 \\
\hline & $31-40$ year & 39 & 37.86 \\
\hline & $41-50$ year & 36 & 34.95 \\
\hline & $\geq 51$ year & 23 & 22.34 \\
\hline & Total & 103 & 100 \\
\hline \multirow[t]{6}{*}{3.} & \multicolumn{3}{|l|}{ Level of education } \\
\hline & Junior high school (SMP) & 7 & 6.8 \\
\hline & Senior high school (SMA) & 53 & 51.46 \\
\hline & Diploma (D3) & 15 & 14.56 \\
\hline & Bachelor (S1) & 28 & 27.18 \\
\hline & Total & 103 & 100 \\
\hline \multirow[t]{6}{*}{4.} & \multicolumn{3}{|l|}{ Years of experience } \\
\hline & 3-5 year & 18 & 17.48 \\
\hline & 6-8 year & 26 & 25.24 \\
\hline & 9-11 year & 42 & 40.78 \\
\hline & $>12$ year & 17 & 16.5 \\
\hline & Total & 103 & 100 \\
\hline
\end{tabular}

\subsection{Results of Data Analysis}

Based on the results of the questionnaire validation, there were two invalid indicators, namely, transformational leadership indicator (i.e., Encouraging followers to show the best performance/TL4 $=0.244)$ and employee performance indicator (i.e., Ability to do work $/ E P 5=0.375$ ). The two invalid indicators were subsequently deleted and removed to improve this research model. The results of statistical data analysis using SEM with the SmartPLS 3 software package are as follows.

Table 3 and Figure 1 show that all indicators of each variable were above 0.5 . It proves that the data in this study had a very good convergent validity.

Table 4 shows that the AVE square root value of each variable was above 0.6 . It indicates that all variables in this study met the requirements of good discriminant validity. The reliability test results also showed that the composite reliability and Cronbach's Alpha values were above 0.5. It proves that the data of this study were reliable and consistent.
Table 5 displays the hypothesis test results; all five hypotheses were accepted. It implies that a) H1: Perceived Organizational Support had a significant effect on employee performance $(\beta=0.262$; T-Statistics $=2.659)$; b) $\mathrm{H} 2$ : Perceived Organizational Support had a significant effect on affective commitment ( $\beta=0.526$; T-Statistics $=9.105)$; c) H3: Transformational leadership had a significant effect on employee performance $(\beta=0.341$; T-Statistics $=2.874)$; d) H4: Transformational leadership had a significant effect on affective commitment ( $\beta=0.421$; T-Statistics $=5.736$ ); d) H5: Affective commitment had a significant effect on employee performance $(\beta=0.328$; T-Statistics $=2.899)$. $\mathrm{R}$-square value also showed that Perceived Organizational Support and Transformational Leadership affected affective commitment by $66.1 \%$. Furthermore, Perceived Organizational Support, transformational leadership, and affective commitment simultaneously affected employee performance by $65.1 \%$, and the rest were influenced by other factors not identified in this study. 
Table 3: Outer Loadings

\begin{tabular}{|l|c|c|c|c|}
\hline & $\begin{array}{c}\text { Affective } \\
\text { Commitment }\end{array}$ & $\begin{array}{c}\text { Employee } \\
\text { Performance }\end{array}$ & $\begin{array}{c}\text { Perceived Organizational } \\
\text { Support }\end{array}$ & $\begin{array}{c}\text { Transformational } \\
\text { Leadership }\end{array}$ \\
\hline AC1 & 0.638 & & & \\
\hline AC2 & 0.748 & & & \\
\hline AC3 & 0.539 & & & \\
\hline AC4 & 0.689 & & & \\
\hline EP1 & & 0.691 & & \\
\hline EP2 & & 0.710 & & \\
\hline EP3 & & 0.787 & & \\
\hline EP4 & & 0.745 & 0.792 & \\
\hline POS1 & & & 0.772 & \\
\hline POS2 & & & 0.562 & \\
\hline POS3 & & & 0.590 & \\
\hline POS4 & & & & \\
\hline POS5 & & & & 0.654 \\
\hline TL1 & & & & 0.872 \\
\hline TL2 & & & & 0.528 \\
\hline TL3 & & & & \\
\hline TL5 & & & & \\
\hline TL6 & & & & \\
\hline TL7 & & & & \\
\hline
\end{tabular}

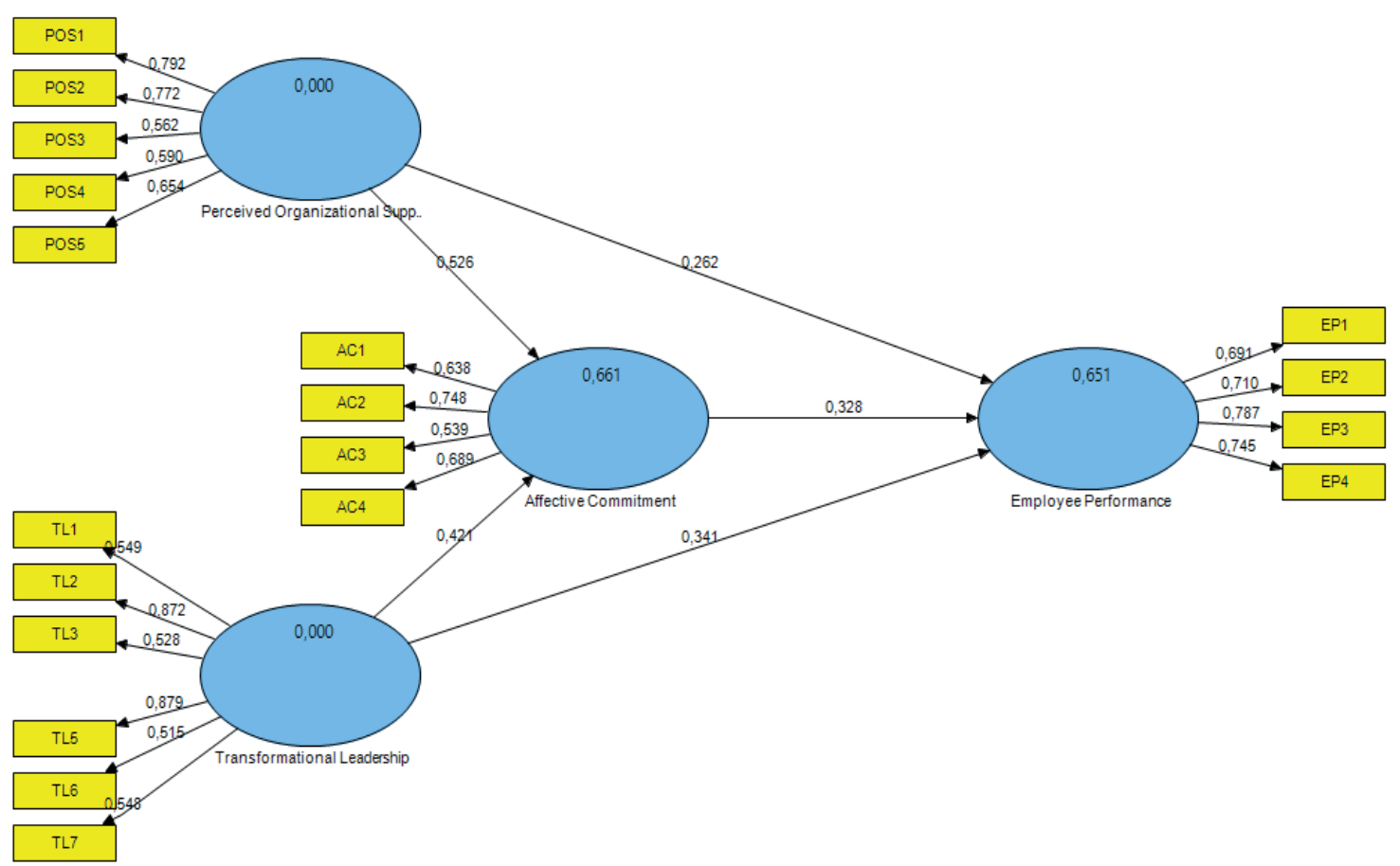

Figure 1: Research Model 
Table 4: Validity and Reliability Test

\begin{tabular}{|l|c|c|c|c|}
\hline Constructs & AVE & $\sqrt{\text { AVE }}$ & Composite Reliability & Cronbach's Alpha \\
\hline Perceived Organizational Support & 0.463 & 0.680 & 0.809 & 0.707 \\
\hline Transformational Leadership & 0.447 & 0.669 & 0.820 & 0.785 \\
\hline Affective Commitment & 0.433 & 0.658 & 0.751 & 0.558 \\
\hline Employee Performance & 0.538 & 0.733 & 0.823 & 0.721 \\
\hline
\end{tabular}

Table 5: Path Coefficients

\begin{tabular}{|l|c|c|c|c|c|}
\hline & $\boldsymbol{\beta}$ & $\begin{array}{c}\text { Sample } \\
\text { Mean }\end{array}$ & $\begin{array}{c}\text { Standard } \\
\text { Deviation }\end{array}$ & T Statistics & Result \\
\hline $\begin{array}{l}\text { Perceived Organizational Support } \rightarrow \\
\text { Employee Performance }\end{array}$ & 0.262 & 0.269 & 0.099 & 2.659 & Accepted \\
\hline $\begin{array}{l}\text { Perceived Organizational Support } \rightarrow \text { Affective } \\
\text { Commitment }\end{array}$ & 0.526 & 0.529 & 0.058 & 9.105 & Accepted \\
\hline $\begin{array}{l}\text { Transformational Leadership } \rightarrow \text { Employee } \\
\text { Performance }\end{array}$ & 0.341 & 0.341 & 0.119 & 2.874 & Accepted \\
\hline $\begin{array}{l}\text { Transformational Leadership } \rightarrow \text { Affective } \\
\text { Commitment }\end{array}$ & 0.421 & 0.423 & 0.073 & 5.736 & Accepted \\
\hline $\begin{array}{l}\text { Affective Commitment } \rightarrow \text { Employee } \\
\text { Performance }\end{array}$ & 0.328 & 0.324 & 0.113 & 2.899 & Accepted \\
\hline
\end{tabular}

This study's results prove that Perceived Organizational Support (POS) significantly influenced employee performance and affective commitment. POS can be seen as the cooperation or support needed to do the job effectively. Employees always form general beliefs regarding how much the organization values contributions and pays attention to their well-being, which in turn will further strengthen loyalty and encourage performance of employees in the organization. Employees are always committed to organizations that support their social-emotional well-being (Ullah et al., 2020). When employees feel that the organization is very supportive and concerned about their well-being, they will make every effort to help and support the organization achieve its goals. It is done as a form of 'repay' (repayment and reciprocity) to the organization by producing more profitable work outcomes, such as higher organizational commitment and performance, as well as disobedience and lower absence behavior. The results of previous studies also have reinforced the finding that POS had a significant effect on affective commitment and employee performance (Arshadi \& Hayavi, 2013; Caesens et al., 2017; Gaudet \& Tremblay, 2017; Liu et al., 2019; Stinglhamb et al., 2020; Yogalakshmi \& Suganthi, 2020).

This study's results confirm that transformational leadership is an essential factor influencing employee performance and affective commitment. Kim (2014), Li et al. (2017) also reinforce that theoretically and empirically, transformational leadership can be associated with improved performance and affective commitment of employees in organizations. Transformational leaders integrate employees' work responsibilities with an attractive vision that can make them feel more meaningful work, thus encouraging increased work performance. With the motivation, encouragement, and trust of transformational leaders, employees feel very confident that they can carry out their duties well and are loyal to the organization. Transformational leaders also provide high stimulus knowledge, skills, and support to employees to effectively complete their work (Bass, 1985). The findings in this study are also strengthened by several previous studies, which concluded that transformational leadership had a significant effect on employee performance and affective commitment (Alghusin \& Al-Ajlouni, 2020; Khan et al., 2019; Mañas-Rodríguez et al., 2020; Pradhan \& Pradhan, 2015).

The results of this study confirm that affective commitment could improve employee creativity and performance. Creative work behavior is related to autonomy, freedom, perseverance, professional achievement, persistence, and dedication at work, where these features stimulate the formation of affection bonds between employees and organizations to encourage increased employee creativity in their workplaces. From a social exchange perspective, employees with firm 
affective commitments can create and implement new and original solutions to improve organizational effectiveness (Montani et al., 2017). Thus, when employees are affectively committed to the organization, they aim to contribute and develop more creative work behaviors. The results of this study are reinforced and supported by several previous studies, which have proven that affective commitment increase employee performance in a positive direction (Moussa \& Arbi, 2020; Djastuti et al., 2019; Hardiningsih et al., 2020; Semedo et al., 2016; Udin et al., 2017).

\section{Conclusion}

The results of this study concluded that POS and transformational leadership significantly influenced employee performance and affective commitment. Furthermore, affective commitment also had a significant effect on employee performance. The results of this study provided some significant managerial implications. First, the findings in this study indicated that POS and transformational leadership had a positive effect on affective commitment and employee performance. The development of transformational leadership could effectively be done through training programs in organizations. Specifically, organizations must develop core transformational leadership competencies, such as communication skills in conveying vision, displaying the right role-models, empowering followers, and building good interpersonal skills. Second, affective commitment tended to be a strong driver of employee performance. Therefore, organizations must choose loyal, proactive, and have high initiative employees to display the best performance to maintain and develop the organization in a sustainable manner.

Although this research produced some essential findings in the development of science, especially human resource management, it still has some limitations that can be resolved by further research. First, one indicator of transformational leadership (i.e., Encouraging followers to show the best performance) and indicator of employee performance (i.e., Ability to do work) were omitted due to validity issues. This negligence is believed to be able to influence the results of the research. Therefore, future research with different constructs is needed to re-explore the relationship. Second, the sample of this study only covered employees in the mill. The managerial and leadership style of the stone grinding sector is usually different from other organizations. Therefore, future research needs to expand the sample to other product/service sectors.

\section{References}

Abou-Moghli, A. (2015). The role of organizational support in improving employees performance. International Business Research, 8(2), 198-203.
Alghusin, N., \& Al-Ajlouni, M. I. (2020). Transformational leadership as an antecedent for organisational commitment and job performance in the banking sector of Jordan. International Journal of Productivity and Quality Management, 30(2), 186-213. doi: https://doi.org/10.1504/IJPQM.2020.107814

Alpkan, L., Bulut, C., Gunday, G., Ulusoy, G., \& Kilic, K. (2010). Organizational support for intrapreneurship and its interaction with human capital to enhance innovative performance. Management Decision, 48(5), 732-755.

Arshadi, N., \& Hayavi, G. (2013). The Effect of Perceived Organizational Support on Affective Commitment and Job Performance: Mediating Role of OBSE. Procedia - Social and Behavioral Sciences, 84, 739-743. doi: https://doi. org/10.1016/j.sbspro.2013.06.637

Astrachan, C. B., Patel, V. K., \& Wanzenried, G. (2014). A Comparative Studyof CB-SEM and PLS-SEM for Theory development in Family Firm Research. Journal of Family Business Strategy, 5, 116-128.

Avolio, B. J., Bass, B. M., \& Jung, D. I. (1999). Re-examining the components of transformational and transactional leadership using the Multifactor Leadership. Journal of Occupational and Organizational Psychology, 72(4), 441-462.

Bass, B. M. (1985). Leadership and performance beyond expectations. New York, NY: The Free Press.

Ben Moussa, N., \& El Arbi, R. (2020). The impact of Human Resources Information Systems on individual innovation capability in Tunisian companies: The moderating role of affective commitment. European Research on Management and Business Economics, 26(1), 18-25. doi: https://doi. org/10.1016/j.iedeen.2019.12.001

Bloemer, J., Pluymaekers, M., \& Odekerken, A. (2013). Trust and affective commitment as energizing forces for export performance. International Business Review, 22(2), 363-380.

Bono, J. E., \& Judge, T. A. (2003). Self-concordance at work: Toward understanding the motivational effects of transformational leaders. Academy of Management Journal, 46, 554-571.

Bratton, J., \& Gold, J. (2017). Human resource management: theory and practice. London, UK: Palgrave Macmillan.

Buil, I., Martínez, E., \& Matute, J. (2019). Transformational leadership and employee performance: The role of identification, engagement and proactive personality. International Journal of Hospitality Management, 77, 64-75. doi: https://doi. org/10.1016/j.ijhm.2018.06.014

Burns, J. M. (1978). Leadership. New York, NY: Harper and Row.

Caesens, G., Stinglhamber, F., Demoulin, S., \& De Wilde, M. (2017). Perceived organizational support and employees' wellbeing: the mediating role of organizational dehumanization. European Journal of Work and Organizational Psychology, 26(4), 527-540. doi: 10.1080/1359432X.2017.1319817

Chen, C.-F., \& Kao, Y.-L. (2014). Investigating the moderating effects of service climate on personality, motivation, social support, and performance among flight attendants. Tourism Management, 44, 58-66. 
Chen, T., Hao, S., Ding, K., Feng, X., Li, G., \& Liang, X. (2020). The impact of organizational support on employee performance: evidence from the automotive industry with flexible manufacturing in China. Employee Relations, 42(1), 166-179. https://doi.org/10.1108/ER-01-2019-0079.

Cheong, M., Spain, S. M., Yammarino, F. J., \& Yun, S. (2016). Two faces of empowering leadership: Enabling and burdening. The Leadership Quarterly, 27(4), 602-616.

Chiang, C.-F., \& Hsieh, T.-S. (2012). The impacts of perceived organizational support and psychological empowerment on job performance: The mediating effects of organizational citizenship behavior. International Journal of Hospitality Management, 31(1), 180-190.

Colla, E., Ruiz-Molina, M. E., Chastenet De Gery, C., Schultz, M., Deparis, M., \& Lemmet, L. (2019). Understanding franchisee performance: The role of the franchisee's autonomy, affective commitment to the network and innovativeness. International Journal of Retail \& Distribution Management, 47(7), 733-751. doi:10.1108/IJRDM-10-2017-0232

Cullen, K. L., Edwards, B. D., Casper, W. C., \& Gue, K. R. (2014). Employees' adaptability and perceptions of change-related uncertainty: Implications for perceived organizational support, job satisfaction, and performance. Journal of Business and Psychology, 29(2), 269-280.

Djastuti, I., Rahardjo, S., Irviana, L., \& Udin, U. (2019). Fun at work and employee performance: the roles of job satisfaction and organizational commitment in manufacturing companies. WSEAS Transactions on Business and Economics, 16, 153-162.

Dumdum, U. R., Lowe, K. B., \& Avolio, B. J. (2002). A metaanalysis of transformational and transactional leadership correlates of effectiveness and satisfaction: An update and extension. Oxford, UK: Elsevier Science.

Eisenberger, R., Shoss, M. K., Karagonlar, G., Gonzalez-Morales, M. G., Wickham, R. E., \& Buffardi, L. C. (2014). The supervisor POS-LMX-subordinate POS chain: Moderation by reciprocation wariness and supervisor's organizational embodiment. Journal of Organizational Behavior, 35(5), 635656.

Eliyana, A., Ma'arif, S., \& Muzakki. (2019). Job satisfaction and organizational commitment effect in the transformational leadership towards employee performance. European Research on Management and Business Economics, 25(3), 144-150. https://doi.org/10.1016/j.iedeen.2019.05.001

Fong, K. H., \& Snape, E. (2015). Empowering leadership, psychological empowerment and employee Outcomes: Testing a multi-level mediating model. British Journal of Management, 26(1), 126-138.

Ganesan, S., Brown, S. P., Mariadoss, B. J., \& Ho, H. (2010). Buffering and amplifying effects of relationship commitment in business-to-business relationships. Journal of Marketing Research, 47(2), 361-373.

Gaudet, M.-C., \& Tremblay, M. (2017). Initiating structure leadership and employee behaviors: The role of perceived organizational support, affective commitment and leadermember exchange. European Management Journal, 35(5), 663-675. https://doi.org/10.1016/j.emj.2017.04.001

Guan, X., Sun, T., Hou, Y., Zhao, L., Luan, Y.-Z., \& Fan, L.H. (2014). The relationship between job performance and perceived organizational support in faculty members at Chinese universities: a questionnaire survey. BMC Medical Education, 14, 50. https://doi.org/10.1186/1472-6920-14-50

Gupta, V., Agarwal, U. A., \& Khatri, N. (2016). The relationships between perceived organizational support, affective commitment, psychological contract breach, organizational citizenship behaviour and work engagement. Journal of Advanced Nursing, 72(11), 2806-2817.

Gyensare, M., Anku-Tsede, O., Sanda, M., \& Okpoti, C. (2016). Transformational leadership and employee turnover intention. World Journal of Entrepreneurship, Management and Sustainable Development, 12(3), 243-266.

Hair, J. F., Black, W., Babin, B. J., \& Anderson, R. (2010). Multivariate data analysis (7th ed.). Upper Saddle River, NJ: Prentice Hall.

Hakimian, F., Farid, H., Ismail, M.N., \& Nair,P. K.(2016). Importance of commitment in encouraging employees' innovative behaviour. Asia-Pacific Journal of Business Administration, 8(1), 70-83. doi: doi:10.1108/APJBA-06-2015-0054

Hardiningsih, P., Udin, U., Masdjojo, G. N., \& Srimindarti, C. (2020). Does Competency, Commitment, and Internal Control Influence Accountability? Journal of Asian Finance, Economics and Business, 7(4), 223-233. doi: https://doi.org/10.13106/ jafeb.2020.vol7.no4.223

Jaiswal, N. K., \& Dhar, R. L. (2015). Transformational leadership, innovation climate, creative self-efficacy and employee creativity: A multilevel study. International Journal of Hospitality Management, 51, 30-41. doi: https://doi. org/10.1016/j.ijhm.2015.07.002

Jatmiko, B., Laras, T., \& Rohmawati, A. (2020). Budgetary Participation, Organizational Commitment, and Performance of Local Government Apparatuses. Journal of Asian Finance, Economics and Business, 7(7), 379-390. doi: https://doi. org/10.13106/jafeb.2020.vol7.no7.379

Jauhari, H., Singh, S., \& Kumar, M. (2017). How does transformational leadership influence proactive customer service behavior of frontline service employees? Examining the mediating roles of psychological empowerment and affective commitment. Journal of Enterprise Information Management, 30(1), 30-48. doi: doi:10.1108/JEIM-01-2016-0003

Judge, T. A., \& Piccolo, R. F. (2004). Transformational and transactional leadership: a meta-analytic test of their relative validity. Journal of Applied Psychology, 89(5), 755-768. https://doi.org/10.1037/0021-9010.89.5.755

Jung, D. I., Chow, C., \& Wu, A. (2003). The role of transformational leadership in enhancing organizational innovation: Hypotheses and some preliminary findings. The Leadership Quarterly, 14(4-5), 525-544. 
Kammerhoff, J., Lauenstein, O., \& Schütz,A. (2019). Leading toward harmony - Different types of conflict mediate how followers' perceptions of transformational leadership are related to job satisfaction and performance. European Management Journal, 37(2), 210-221. https://doi.org/10.1016/j.emj.2018.06.003

Kankanhalli, A., Tan, B. C., \& Wei, K.-K. (2005). Contributing knowledge to electronic knowledge repositories: An empirical investigation. MIS Quarterly, 29(1), 113-143. DOI: $10.2307 / 25148670$

Karatepe, O. M., \& Sokmen, A. (2006). The effects of work role and family role variables on psychological and behavioral outcomes of frontline employees. Tourism Management, 27(2), 255-268.

Khan, A. N., Ali, A., Khan, N. A., \& Jehan, N. (2019). A study of relationship between transformational leadership and task performance: The role of social media and affective organisational commitment. International Journal of Business Information Systems, 31(4), 499-516. https://doi.org/10.1504/ IJBIS.2019.101583

Kim, H. (2014). Transformational Leadership, Organizational Clan Culture, Organizational Affective Commitment, and Organizational Citizenship Behavior: A Case of South Korea's Public Sector. Public Organization Review, 14(3), 397-417. doi: $10.1007 / \mathrm{s} 11115-013-0225-\mathrm{z}$

Kirkman, B. L., Chen, G., Farh, J.-L., Chen, Z. X., \& Lowe, K. B. (2009). Individual Power Distance Orientation And Follower Reactions To Transformational Leaders: A Cross-Level, CrossCultural Examination. Academy of Management Journal, 52(4), 744-764.

Kumar, R. (2005). Research Methodology-A Step-by-Step Guide for Beginners (2nd ed.). Singapore: Pearson Education.

Li, J., Kim, W. G., \& Zhao, X. (2017). Multilevel model of management support and casino employee turnover intention. Tourism Management, 59, 193-204. https://doi.org/10.1016/j. tourman.2016.08.006

Li, J., \& Yuan, B. (2017). Both angel and devil: The suppressing effect of transformational leadership on proactive employee's career satisfaction. International Journal of Hospitality Management, 65, 59-70. https://doi.org/10.1016/j.ijhm.2017.06.008

Liu, Y., Ye, L., \& Guo, M. (2019). The influence of occupational calling on safety performance among train drivers: The role of work engagement and perceived organizational support. Safety Science, 120, 374-382. https://doi.org/10.1016/j. ssci.2019.07.025

Luo, A., Guchait, P., Lee, L., \& Madera, J. M. (2019). Transformational leadership and service recovery performance: The mediating effect of emotional labor and the influence of culture. International Journal of Hospitality Management, 77, 31-39. https://doi.org/10.1016/j.ijhm.2018.06.011

MacKenzie, S. B., Podsakoff, P. M., \& Rich, G. A. (2001). Transformational and Transactional Leadership and Salesperson Performance. Journal of the Academy of Marketing Science, 29(2), 115-134.
Mañas-Rodríguez, M.-Á., Díaz-Fúnez, P.-A., Llopis-Marín, J., Nieto-Escámez, F., \& Salvador-Ferrer, C. (2020). Relationship between transformational leadership, affective commitment and turnover intention of workers in a multinational company. International Journal of Social Psychology, 35(1), 100-115. doi: 10.1080/02134748.2019.1682292

Martono, S., Khoiruddin, M., Wijayanto, A., Ridloah, S., Wulansari, N. A., \& Udin, U. (2020). Increasing Teamwork, Organizational Commitment and Effectiveness through the Implementation of 9borative Resolution. Journal of Asian Finance, Economics and Business, 7(6), 427-437. https://doi. org/10.13106/jafeb.2020.vol7.no6.427

Meyer, J. P., \& Allen, N. J. (1991). A three-component conceptualization of organizational commitment. Human Resource Management Review, 1(1), 61-89.

Montani, F., Courcy, F., \& Vandenberghe, C. (2017). Innovating under stress: The role of commitment and leader-member exchange. Journal of Business Research, 77, 1-13. https://doi. org/10.1016/j.jbusres.2017.03.024

Nicolaou, A. I., \& Masoner, M. M. (2013). Sample size requirements in structural equation models under standard conditions. International Journal of Accounting Information Systems, 14(4), 256-274.

Palmatier, R. W., Dant, R. P., \& Grewal, D. (2007). A comparative longitudinal analysis of theoretical perspectives of interorganizational relationship performance. Journal of Marketing, 71(4), 172-194.

Pancasila, I., Haryono, S., \& Sulistyo, B. A. (2020). Effects of Work Motivation and Leadership toward Work Satisfaction and Employee Performance: Evidence from Indonesia. Journal of Asian Finance, Economics and Business, 7(6), 387-397. https:// doi.org/10.13106/jafeb.2020.vol7.no6.387

Park, J. H., Newman, A., Zhang, L., Wu, C., \& Hooke, A. (2016). Mentoring functions and turnover intention: The mediating role of perceived organizational support. The International Journal of Human Resource Management, 27(11), 1173-1191.

Piccolo, R. F., \& Colquitt, J. A. (2006). Transformational leadership and job behaviors: The mediating role of core job characteristics. Academy of Management Journal, 49(2), 327-340.

Pradhan, S., \& Pradhan, R. K. (2015). An Empirical Investigation of Relationship among Transformational Leadership, Affective Organizational Commitment and Contextual Performance. Vision, 19(3), 227-235. doi: 10.1177/0972262915597089

Rhoades, L., \& Eisenberger, R. (2002). Perceived organizational support: a review of the literature. Journal of Applied Psychology, 87(4), 698-714.

Sears, G. J., Zhang, H., \& Han, Y. (2016). Negative affectivity as a moderator of perceived organizational support-work outcome relationships. Personality and Individual Differences, 98, 257-260.

Semedo, A. S. D., Coelho, A. F. M., \& Ribeiro, N. M. P. (2016). Effects of authentic leadership, affective commitment and job resourcefulness on employees' creativity and individual 
performance. Leadership \& Organization Development Journal, 37(8), 1038-1055. https://doi.org/10.1108/LODJ-022015-0029

Shaheen, M., \& Krishnankutty, R. (2018). The mediation of psychological capital in the relationship of perceived organizational support, engagement and extra-role performance. International Journal of Knowledge Management, 14(4), 30-45.

Shanker, R., Bhanugopan, R., Van der Heijden, B. I., \& Farrell, M. (2017). Organizational climate for innovation and organizational performance: The mediating effect of innovative work behavior. Journal of Vocational Behavior, 100, 67-77.

Shantz, A., Alfes, K., \& Latham, G. P. (2016). The buffering effect of perceived organizational support on the relationship between work engagement and behavioral outcomes. Human Resource Management, 55(1), 25-38.

Stinglhamber, F., Marique, G., Caesens, G., Hanin, D., \& De Zanet, F. (2015). The influence of transformational leadership on followers' affective commitment. Career Development International, 20(6), 583-603.

Stinglhamber, F., Ohana, M., Caesens, G., \& Meyer, M. (2020). Perceived organizational support: the interactive role of coworkers' perceptions and employees' voice. Employee Relations: The International Journal, 42(1), 107-124. https:// doi.org/10.1108/ER-05-2018-0137

Tsai, C.-Y., Horng, J.-S., Liu, C.-H., \& Hu, D.-C. (2015). Work environment and atmosphere: The role of organizational support in the creativity performance of tourism and hospitality organizations. International Journal of Hospitality Management, 46, 26-35.

Udin, Handayani, S., Yuniawan, A., \& Rahardja, E. (2017). Antecedents and Consequences of Affective Commitment among Indonesian Engineers Working in Automobile Sector: An Investigation of Affecting Variables for Improvement in Engineers Role. International Journal of Civil Engineering and Technology, 8(10), 70-79.

Ullah, I., Elahi, N. S., Abid, G., \& Butt, M. U. (2020). The impact of perceived organizational support and proactive personality on affective commitment: mediating role of prosocial motivation. Business, Management and Education, 18(2), 183-205.
Vandenberghe, C., Bentein, K., \& Stinglhamber, F. (2004). Affective commitment to the organization, supervisor, and work group: Antecedents and outcomes. Journal of Vocational Behavior, 64(1), 47-71.

Vatankhah, S., Javid, E., \& Raoofi, A. (2017). Perceived organizational support as the mediator of the relationships between high-performance work practices and counterproductive work behavior: Evidence from airline industry. Journal of Air Transport Management, 59, 107-115.

Vuong, B. N., Tung, D. D., Hoa, N. D., Chau, N. T. N., \& Tushar, H. (2020). An Empirical Assessment of Organizational Commitment and Job Performance: Vietnam Small and MediumSized Enterprises. Journal of Asian Finance, Economics and Business, 7(6), 277-286. https://doi.org/10.13106/jafeb.2020. vol7.no6.277

Wann-Yih, W., \& Htaik, S. (2011). The Impacts of perceived organizational support, job satisfaction, and organizational commitment on job performance in hotel industry. Paper presented at the The 11th International DSI and the 16th APDSI Joint Meeting, Taipei, Taiwan, July.

Xiong, L., \& King, C. (2018). Too much of a good thing? Examining how proactive personality affects employee brand performance under formal and informal organizational support. International Journal of Hospitality Management, 68, $12-22$.

Xiu, L., Dauner, K. N., \& McIntosh, C. R. (2019). The impact of organizational support for employees' health on organizational commitment, intent to remain and job performance. Paper presented at the Evidence-based HRM: a Global Forum for Empirical Scholarship.

Yavas, U., Karatepe, O. M., \& Babakus, E. (2010). Relative efficacy of organizational support and personality traits in predicting service recovery and job performances: a study of frontline employees in Turkey. Tourism Review, 65(3), 70-83.

Yogalakshmi, J. A., \& Suganthi, L. (2020). Impact of perceived organizational support and psychological empowerment on affective commitment: Mediation role of individual career self-management. Current Psychology, 39(3), 885-899. doi: $10.1007 / \mathrm{s} 12144-018-9799-5$ 